\title{
SIMULATING WATER AND SOIL GUSHING AROUND SHIELD TUNNEL WITH MATERIAL POINT METHOD
}

\author{
XIAO-CHUANG XIE ${ }^{*} 1$, FRANCESCA CECCATO ${ }^{\dagger 2}$, DONG-MEI ZHANG ${ }^{\dagger 3}$ AND \\ MING-LIANG ZHOU ${ }^{\dagger 4}$ \\ ${ }^{* 1}$ Department of Geotechnical Engineering College of Civil Engineering \\ Tongji University \\ 1239 Siping Road, Shanghai 200092, China \\ e-mail:1610238@tongji.edu.cn \\ $\dagger^{\dagger 2}$ Department of Civil Environmental and Architectural Engineering (DICEA) \\ University of Padua \\ Via Ognissanti 39, 35129 Padova, Italy \\ e-mail: francesca.ceccato@dicea.unipd.it \\ ${ }^{\dagger 3}$ Department of Geotechnical Engineering College of Civil Engineering \\ Tongji University \\ 1239 Siping Road, Shanghai 200092, China \\ e-mail: dmzhang@tongji.edu.cn \\ ${ }^{\dagger 4}$ Department of Geotechnical Engineering College of Civil Engineering \\ Tongji University \\ 1239 Siping Road, Shanghai 200092, China \\ e-mail: dmzhang@tongji.edu.cn
}

Key words: Water and Soil Gushing, MPM, Soil Displacement, Shield Tunnel.

\begin{abstract}
In recent years, serious accidents due to sand and water gushing around shield tunnel happen from time to time. Sand and water gushing could lead to large soil displacement, change soil stress field around tunnels, and then threaten the safety of tunnel structures. To date, there is a lack of theoretical research on the evolution of sand and water gushing, and the numerical simulation of the process is challenging because soil-water interaction, soil-structure interaction and large deformations have to be accounted for. In this paper, the Material Point Method (MPM) is used to deal with large deformation and various simulation cases considering different gushing locations at tunnels are carried out to investigate the development of soil displacement and stress around tunnels due to water and soil gushing. The results show that position of the gushing point greatly affect the damage scope. The sand gushing rate, the soil displacement and stress field, the ground settlement trough, and the earth pressure on the tunnel linings develop completely differently due to the varying position of the gushing point, which are analyzed to suggest reasonable guidance and countermeasures for preventing future sand and water gushing accidents.
\end{abstract}




\section{INTRODUCTION}

Containing a large quantity of joints, holes and other weak points, shield tunnels are very likely to encounter the hazards of sand gushing and water leakage, especially for tunnels in water-rich sandy stratum $[1,2]$. These hazards could affect the normal operation of the tunnel, or even endanger the safety of the tunnel structure, and cause engineering accidents [3-6]. For instance, during the operation of Metro Line 1 in St. Petersburg, the water and soil gushing suddenly occurred in 1995, which caused large ground settlement and the tunnel abandon [3]. For the tunnels under construction, the water and sand would also flow into the tunnel through the weak points in the tunnel segments. In 2019, during the construction of the connecting passage of Shanghai Metro Line 18, due to the opening at the orifice pipes, the sudden sand and water gushing caused the tunnel to deform and the segments were damaged, which were toughly reinforced through a series of remedial measures [7].

A considerable amount of research has been conducted on the water leakage-induced response of the tunnel lining and the deformation of the surrounding soil. This includes experimental investigation [8,9], numerical modelling [10, 11], field observation [7, 12], and analytical solutions [13]. While the sand and water gushing in a tunnel is a more dangerous process in which the soil is continuously lost with the water flow. However, there are few researches on the mechanism and evolution of sand and water gushing in shield tunnels. Under the effect of water seepage, the soil around the tunnel moves dramatically, and the performance of the tunnel structure could be severely influenced. In order to study the process


in depth, the kinematic be obtained reasonably, the pore pressure, the this process should be Due to the complexity it is difficult to reproduce this process using trad
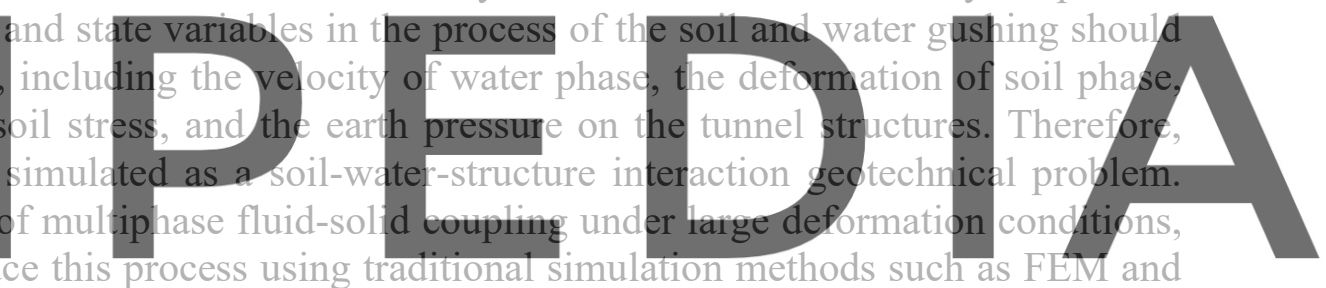
FDM. The literature shows that the Material Point Method (MPM) can reasonably simulate

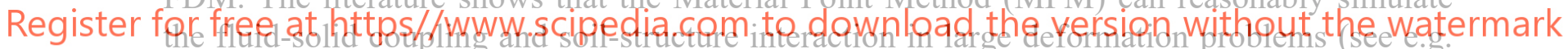

[14-18]). Therefore, the MPM is adopted in this paper to study the evolution of soil stress and strain, the pore pressure, and the earth pressure on the tunnel linings caused by sand and water gushing at different locations of the tunnel.

\section{MPM SIMULATIONS}

MPM is a particle-based method, in which large deformations can be modelled by material points moving through a background mesh. The material points carry all physical information such as velocity, stresses, strains, and other state variables, while the background mesh does not store any permanent information and goes back to its original configuration after each calculation step. In recent years, the MPM has been widely adopted to deal with the geotechnical large deformation problems (see e.g. [17] and references therein). The problem of the water and soil gushing in shield tunnel is simplified as a two-dimensional plane strain problem and simulated using the software Anura3D [19].

To analyze the development of the deformation of the surrounding soil caused by the water and soil gushing at different locations of the shield tunnel, five cases are simulated. The 
typical model configuration is shown in Fig. 1. Half of the tunnel is simulated, because of the symmetry. The geometric size is $30 \mathrm{~m} \times 40 \mathrm{~m}$. The left and right sides of the boundary are constrained horizontally and the bottom boundary is restrained against both horizontal and vertical displacements. The buried depth and the diameter of the tunnel are $20 \mathrm{~m}$ and $6.2 \mathrm{~m}$, respectively. The soil is simulated with the two-phase single-point material type, which takes the velocity of both solid and liquid phase as the primary unknowns [14]. The tunnel is modelled as single-phase dry material with a thickness of $0.35 \mathrm{~m}$. The elastic modulus of the tunnel and the Poisson's ratio are set as $10000 \mathrm{kPa}$ and 0.2 , respectively. The contact algorithm proposed by [20], extended for two-phase problems by [16] is applied at the tunnelsoil interface. The friction coefficient for the interface of soil and tunnel is set as 0.2. The Mohr-Colomb model is used for the soils and the parameters are listed in Table 1. Overall, the grid is composed of $0.75 \mathrm{~m}$ triangular cells with 3 material points per cell. The cell size for the soil domain close to the opening is gradually densified to $0.2 \mathrm{~m}$, with 12 material points per cell.
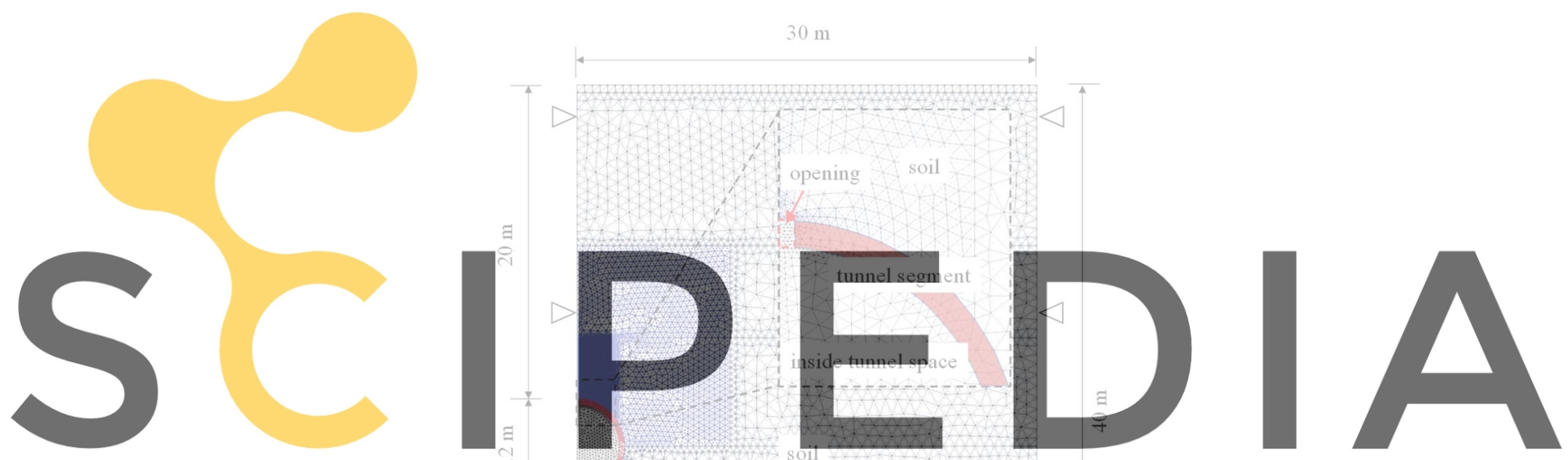

Register for free at https//www.scipedia.com to dowaload the version without the watermark

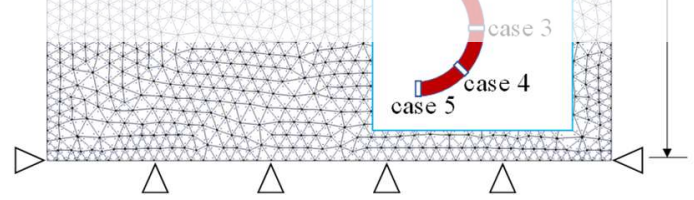

Figure 1: Model configuration

Table 1: Parameters for soil layers

\begin{tabular}{cccc}
\hline Parameter & Symbol & Value & Unit \\
\hline Density of grains & $\rho_{S}$ & 2650 & $\mathrm{~kg} / \mathrm{m}^{3}$ \\
Young's modulus & $E$ & 40000 & $\mathrm{kPa}$ \\
Poisson ratio & $v$ & 0.3 & -- \\
Porosity & $n$ & 0.45 & -- \\
Cohesion & $c$ & 0 & $\mathrm{kPa}$ \\
Friction angle & $\phi$ & 35 & -- \\
Intrinsic permeability & $\kappa$ & $1 \times 10^{-10}$ & $\mathrm{~m}^{2}$ \\
\hline
\end{tabular}




\begin{tabular}{cccc}
\hline Water density & $\rho_{L}$ & 1000 & $\mathrm{~kg} / \mathrm{m}^{3}$ \\
Water bulk modulus & $K_{L}$ & 80000 & $\mathrm{kPa}$ \\
Water viscosity & $\mu_{L}$ & $1.002 \times 10^{-6}$ & $\mathrm{kPa} \cdot \mathrm{s}$ \\
\hline
\end{tabular}

An opening with an inner width of $0.2 \mathrm{~m}$ is pre-set to induce a sudden leakage. Solid-liquid displacement is restrained at the gushing point in the initial state. The procedure of the simulation can be divided into two stages: 1) The equilibrium state of soil is firstly calculated to obtain the initial effective stress and the pore water pressure of the soil before the gushing. 2) Water and soil gushing is then initiated by the removal of opening fixities, and the saturated soil could move into the tunnel.

\section{ANALYSIS OF SIMULATION RESULTS}

Fig. 2 shows the cumulative mass of soil inflowed into the tunnel due to the water and soil gushing at different location of the tunnel. The slope of these curves can represent the rate of the soil gushing. As the gushing location moves downwards, the rate of the soil gushing decreases significantly. For example, when the time is $40 \mathrm{~s}$, the maximum mass of soil gushing is $3.26 \mathrm{~kg} / \mathrm{m}$ in Case 1 , which is almost four times that of Case 5 with $0.82 \mathrm{~kg} / \mathrm{m}$.
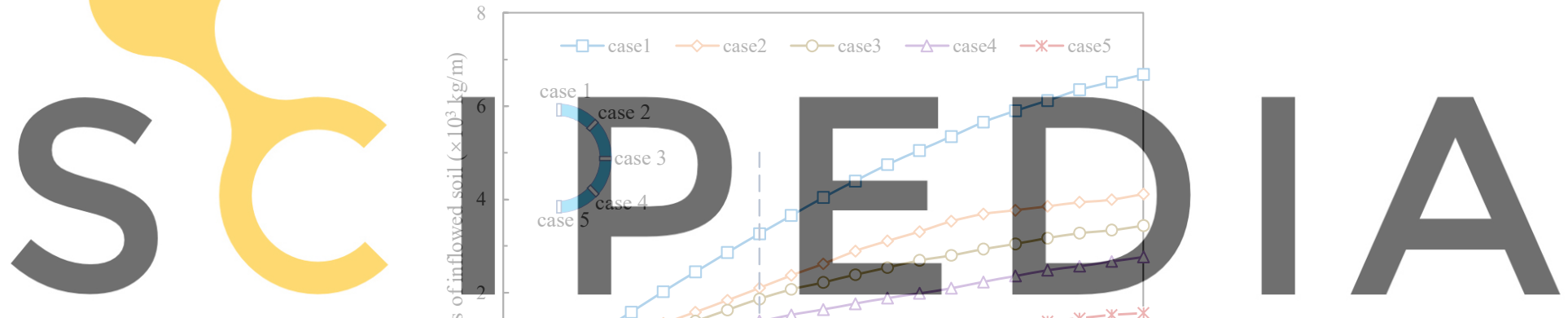

Register for free at https//wyw

Figure 2: Development of soil gushing in different cases

As the gushing location moves downwards, the hydraulic gradient at the opening somewhat increases, while gravity would gradually turn from a driving force to a resistance, thereby reducing the rate of the soil gushing.

\subsection{Evolution of water and soil gushing}

The evolution of soil and water gushing is analyzed in this section referring to Case 1, i.e. gushing point at the tunnel crown. Fig. 3(a) presents the development of the soil total displacement field caused by soil gushing. According to the displacement magnitude, the soil displacement field can be divided into flow zone (displacement $>0.05 \mathrm{~m}$ ), disturbed zone $(0.01 \mathrm{~m}<$ displacement $<0.05 \mathrm{~m})$ and stationary zone (displacement $<0.01 \mathrm{~m})$. When the mass flow gradually increases, the shape of each zone basically remains unchanged. For example, when the mass of soil gushing grows from $500 \mathrm{~kg} / \mathrm{m}$ to $4000 \mathrm{~kg} / \mathrm{m}$, the flow zone 
keeps elliptical, whereas only the displacement magnitude becomes greater. The large deformation gradually expands from the opening to the ground surface, indicating that the inflowed soil is basically supplemented from the flow zone. When the mass of gushing reaches $4000 \mathrm{~kg} / \mathrm{m}$, the radius of the flow zone on the surface is approximately twice the diameter of the tunnel, and that of the disturbed zone is about three times the diameter. Fig. 3(b) shows the development of the deviatoric plastic strain fields caused by the water and soil gushing at the tunnel crown (Case 1). A shear sliding surface develops from the opening to the ground surface with time, which is consistent with the contour of the flow zone in the displacement field.

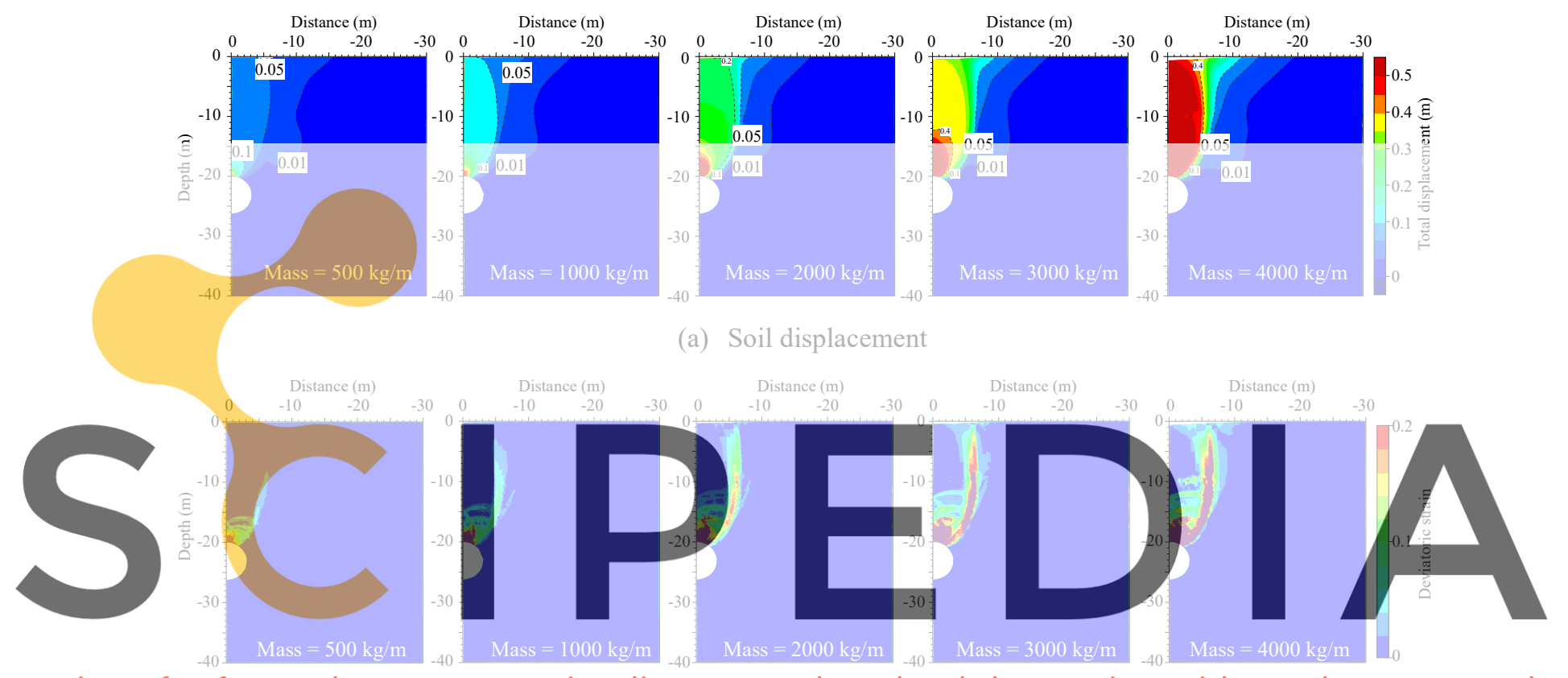

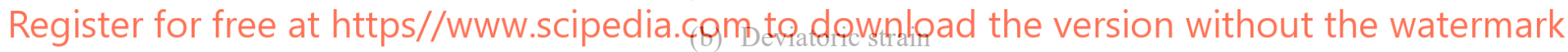

Figure 3: Development of soil displacement and deviatoric strain in Case 1

Fig. 4(a) illustrates the development of the pore pressure around the tunnel. Due to the existence of the opening, pore pressure dissipates, which can be clearly visible from the contour. In the initial state, the pore pressure is the hydrostatic pressure. With the removal of the constraints at the opening, the pore pressure at the opening decreases sharply and it starts to redistribute, decreasing near the tunnel. In general, the pore pressure field rapidly reaches a new equilibrium state and then remains stable.

Fig. 4(b) draws the development of the soil vertical stress with time. When the water and soil gushing start, the soil stress above the opening is released, and the vertical stress of the soil in the flow zone decreases significantly, which is similar to the evolution of the pore pressure field. However, the soil vertical stress below the shear sliding surface increases. According to [21], the dynamic overpressures would occur during the discharge of dry bulk granular solids from silos and other containment structures. It could be concluded that, the overpressures also exist during the soil gushing around the tunnel structures. 


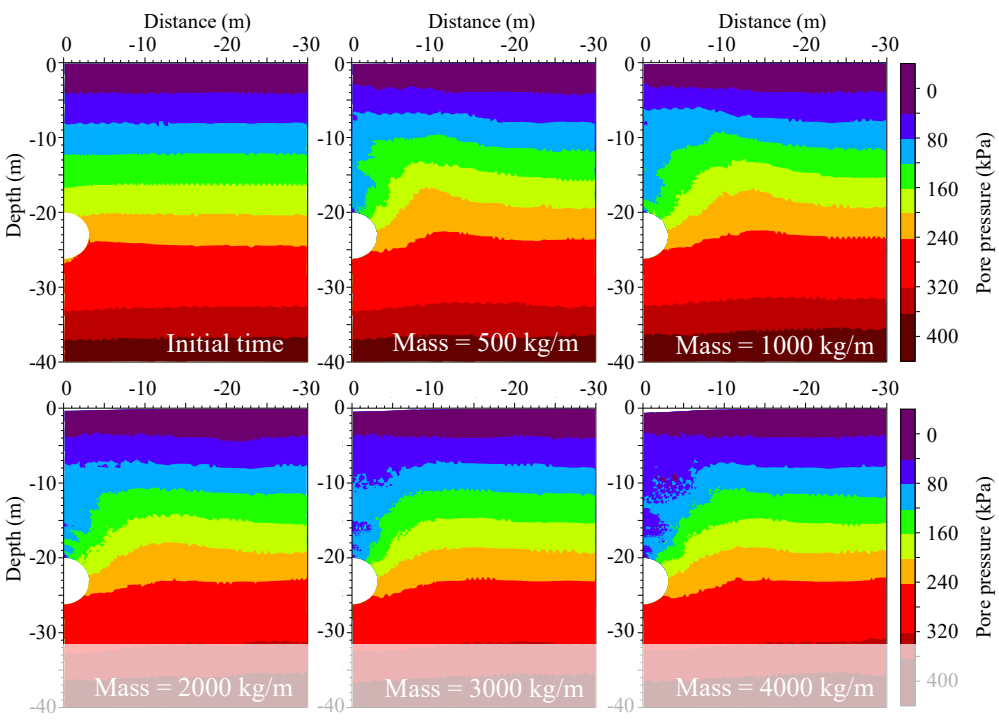

(a) Pore pressure
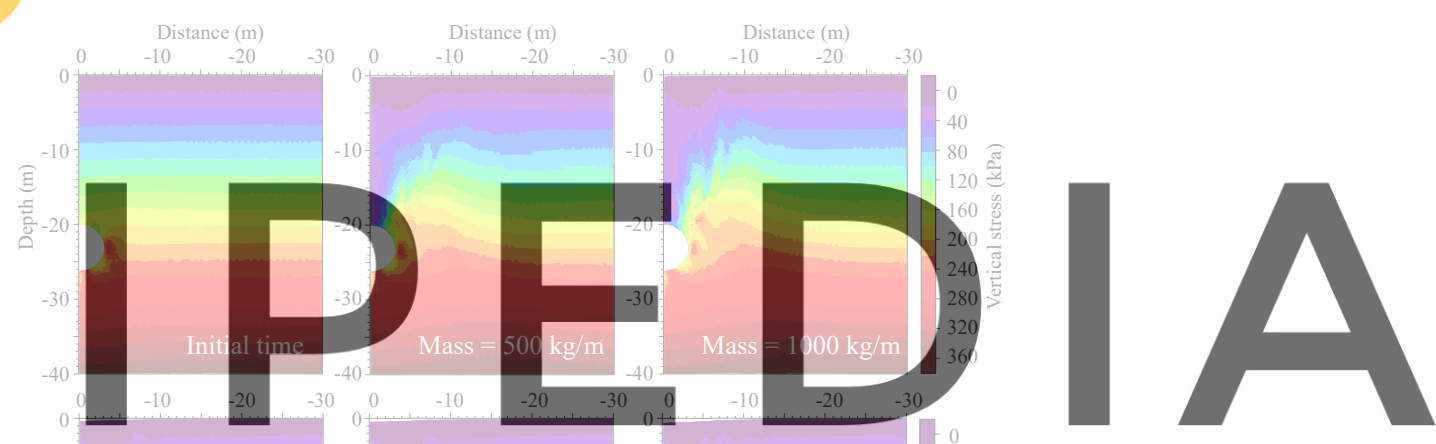

Register for free at https//9ww.scipedia.com to download the version ${ }^{-10}$ without the watermark
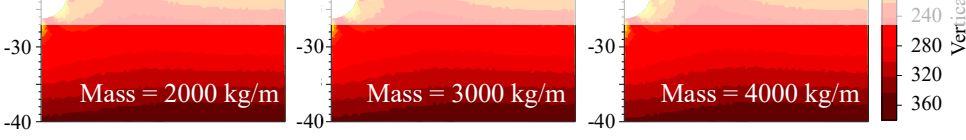

(b) Soil vertical stress

Figure 4: Development of soil vertical stress and pore pressure in Case 1

Changes in the soil stress field around the tunnel will inevitably affect the safety of the tunnel structure. Therefore, in order to further analyze the impact of soil gushing on the tunnel structure, the ratio of the earth pressure after gushing to the initial earth pressure $\eta$ is calculated by Equation (1):

$$
\eta=\frac{p_{t}}{p_{0}}
$$

Where the earth pressures $p_{t}$ and $p_{0}$ are referred as soil pressure normally acting on the tunnel lining at the time $t$ and initial state, respectively. 
As shown in Fig. 5, local soil gushing will affect the external force of the entire tunnel structure. After the gushing occurs, the ratio is less than 1.0 within $40^{\circ}$ of the opening, indicating that the earth pressure at the area will decrease due to the soil gushing. However, because of the overpressures below the shear sliding surface, the earth pressure below $45^{\circ}$ of the tunnel lining increases. With the gushing developing to $1000 \mathrm{~kg} / \mathrm{m}$, the earth pressure at $90^{\circ}$ of the tunnel linings even increases to over 1.5 times the initial value. Therefore, in addition to blocking the gushing opening, it is also necessary to strengthen the structural safety of the tunnel so as to avoid structural collapse.

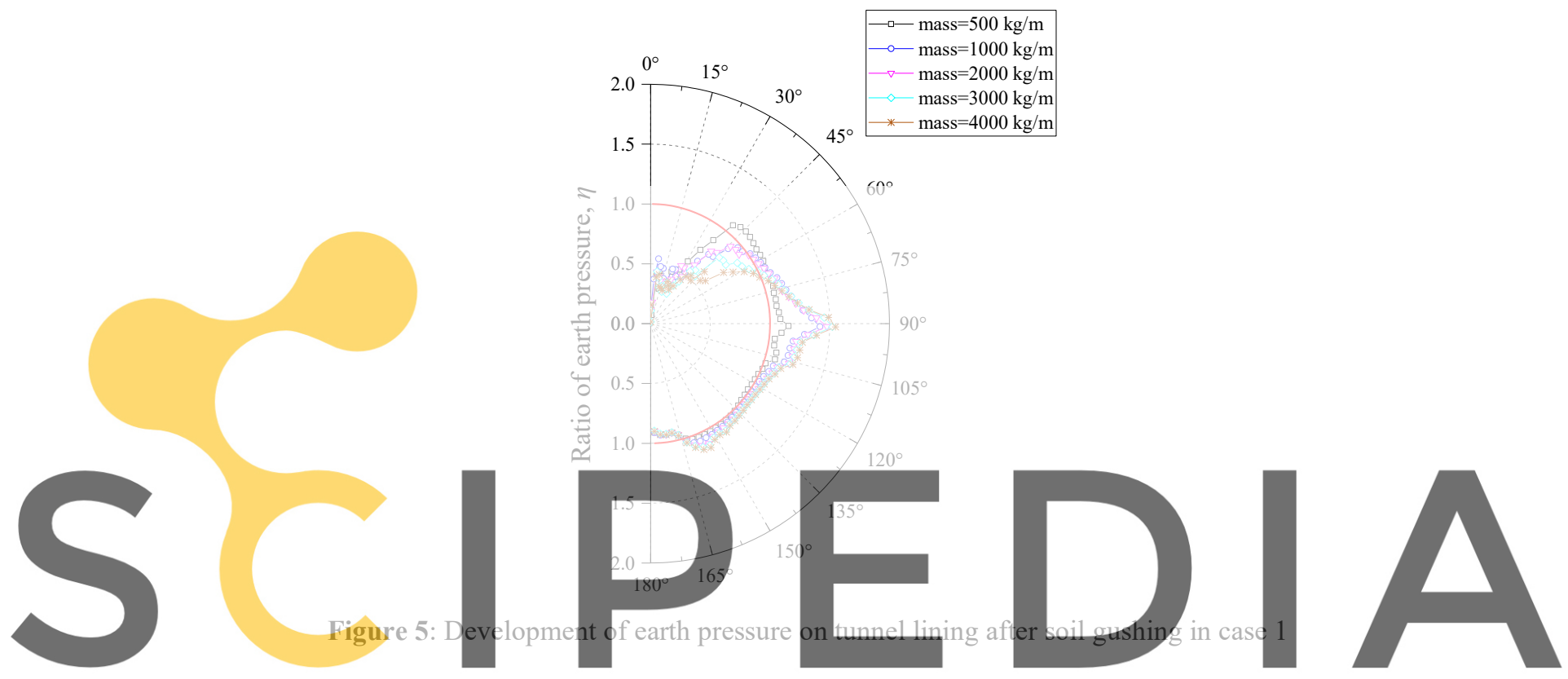

3.2 Soil gushing at different locations of tunnel

Register for free at https//www.scipedia.com to download the version without the watermark In order to analyze the influence of different gushing locations and exclude the impact of different mass of soil gushing, this paper selects each case with a gushing mass of $1000 \mathrm{~kg} / \mathrm{m}$ for comparative analysis, as shown in Fig. 2.

Fig. 6(a) and (b) show the development of the soil displacement and the deviatoric strain fields for all cases. In Case 1 and Case 2, the flow zones expand from the opening to the surface, and the shapes of the disturbed zones are similar. The soil gushing for the two cases both have a greater impact on the soil. As for the soil gushing below $90^{\circ}$ of the tunnel lining (Cases 3-5), the flow zones are smaller, but the disturbed zone are larger than Case 1 and Case 2. The contours of the deviatoric strain fields show that the shear sliding surfaces for Case 1 and Case 2 extend from the opening to the ground surface, whereas those for Cases $3-5$ are located near the opening in the tunnel. These characteristics are consistent with the contour of the flow zone. 

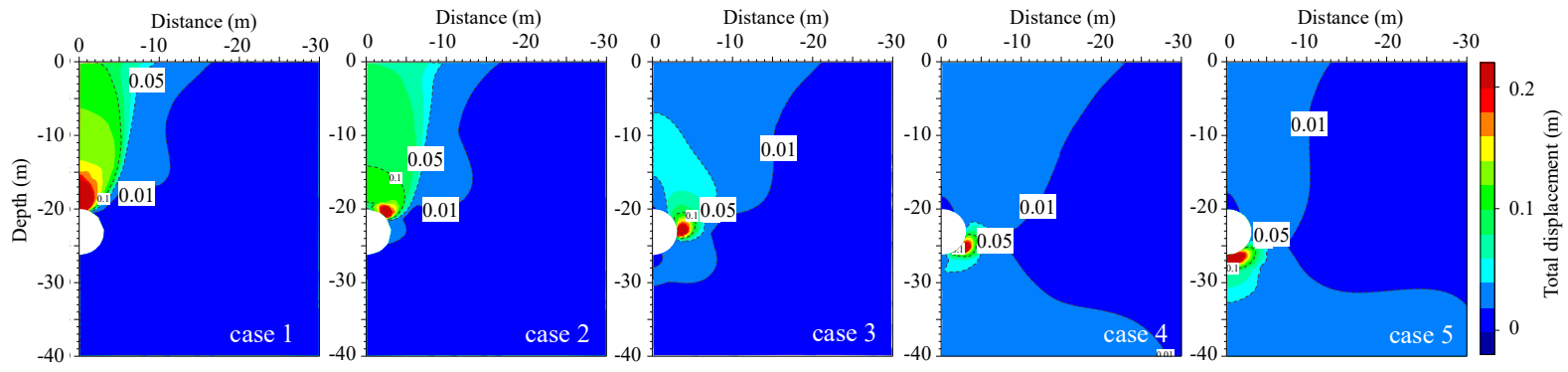

(a) Soil displacement
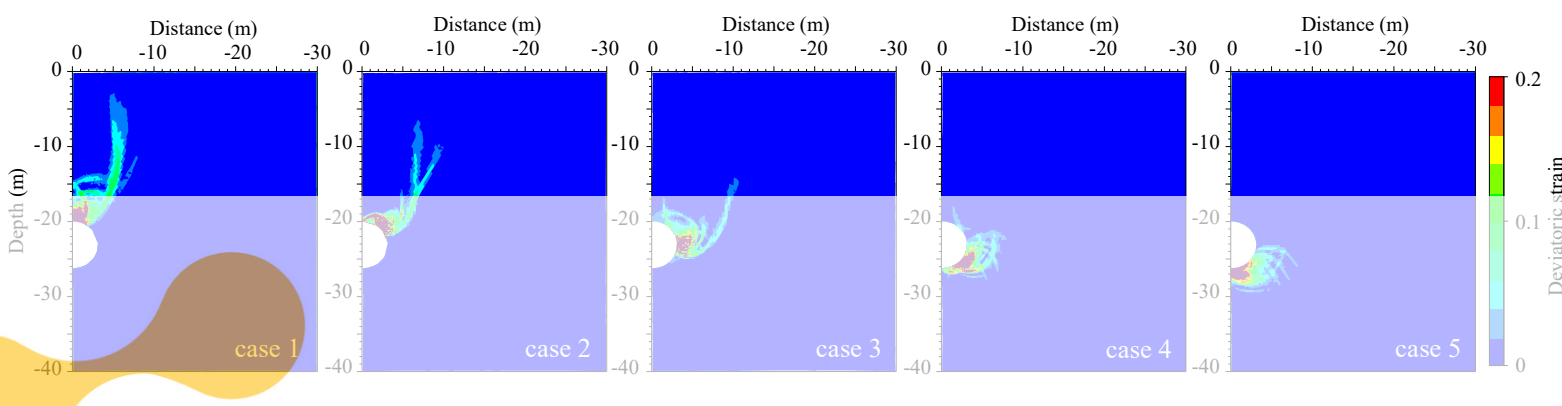

(b) Deviatoric strain
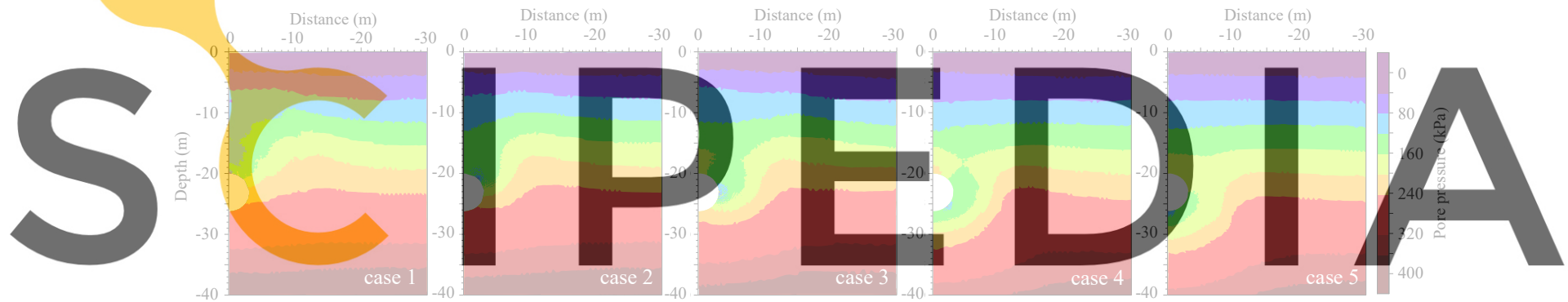

Register for free at https//www.scipedia.com itoedeswndoad the version without the watermark
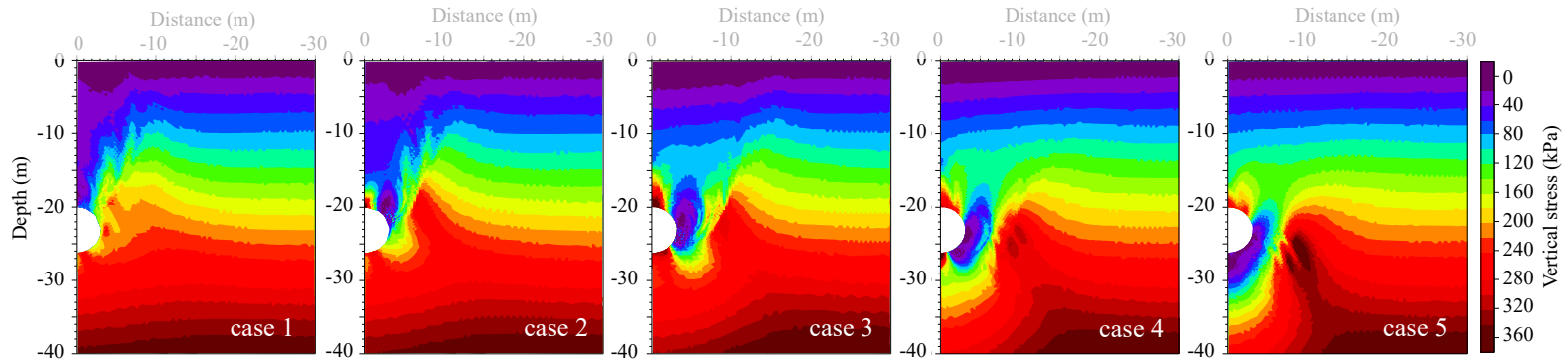

(d) Soil vertical stress

Figure 6: Comparison of the influence of different gushing locations (mass of inflowed soil $=1000 \mathrm{~kg} / \mathrm{m}$ )

Fig. 6(c) and (d) show the development of the pore pressure and the soil stress field for all cases. The isolines of Fig. 6(c) indicate that the pore pressure adjacent to the opening decreases sharply for all cases, resulting in a large hydraulic gradient, which is the main reason of the soil gushing. For Case 1 and Case 2, the pore pressure below the tunnel is scarcely influenced by the soil and water gushing. In addition, the pore pressure above the 
tunnel also keeps stable in Case 4 and Case 5. Fig. 6(d) demonstrates that for all cases, due to the stress-releasing caused by soil gushing, the soil vertical stress around the opening on the tunnel is reduced sharply, and its size is similar to that of the flow zone. In addition, the soil vertical stress below the shear sliding surface increases for all cases. The difference from Case 1 is that the soil vertical stress above the top of the tunnel will increase in Cases 2-5, which may aggravate structural safety problems of the tunnel.

Fig. 7 presents the ratio of earth pressure due to the soil and water gushing in five cases with the same mass of inflowed soil. As the mass of inflowed soil reaches $1000 \mathrm{~kg} / \mathrm{m}$ for each case, the ratio is reduced to zero at the opening of the tunnel lining, indicating that the earth pressure at the opening will decrease dramatically for all cases. For Case 1 and Case 2, the soil gushing mainly affects the upper part of the tunnel, and the ratio of earth pressure at the lower part of the tunnel is approximately 1.0. For Cases 3-5, the earth pressure at entire tunnel lining is influenced and the overpressures at the top of tunnel are particularly significant. For instance, in Case 3, the ratio of earth pressure at $0^{\circ}$ of the tunnel almost reaches 3.0, while the ratio at $90^{\circ}$ is close to zero, which will inevitably influence structural safety.
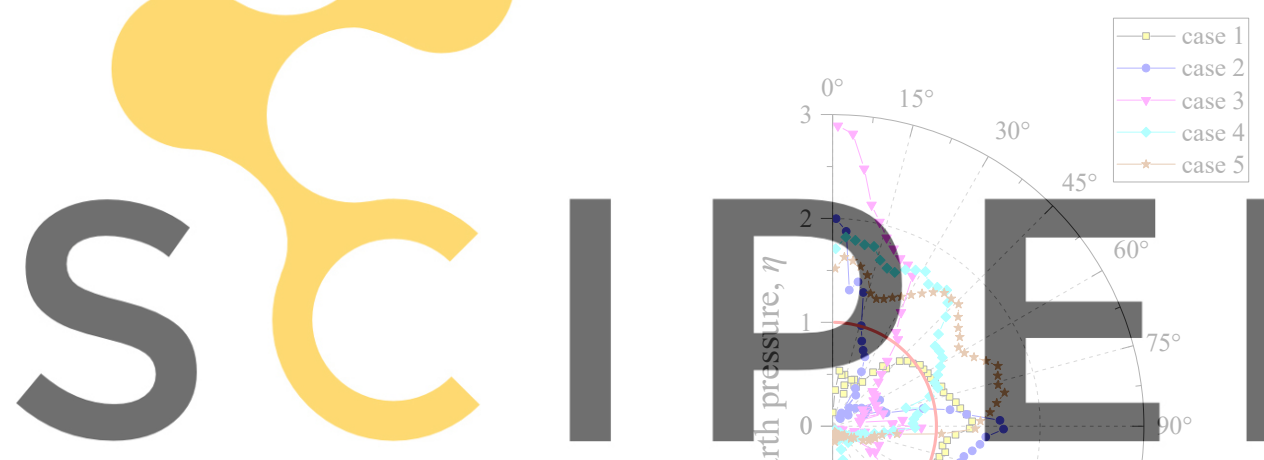

Register for free at https//www.scipeglia.con to download the version without the watermark

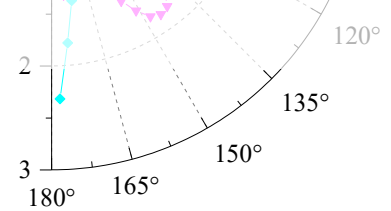

Figure 7: Comparison of earth pressure on tunnel lining after soil gushing in different cases

\section{CONCLUSIONS}

Based on the parametric analysis for the sand and water gushing at different locations of the tunnel, the evolution of soil behavior caused by the gushing is investigated using MPM. The following conclusions are obtained:

- $\quad$ As the gushing location moves downwards, the gravity would gradually turn from a driving force to a resistance for the gushing process, causing the rate of the soil gushing decreasing.

- $\quad$ The soil displacement field caused by the water and soil gushing can be divided into 
flow zone, disturbed zone, and stationary zone. The contour of the flow zone is consistent with the shear sliding surface, which develops from the opening to the ground surface.

- With the removal of the constraints at the opening, the pore pressure and soil stress field start to redistribute. The pore pressure and soil vertical stress at the opening decrease sharply. However, the overpressures also exist around the opening during the soil gushing process.

- $\quad$ The flow zones in Case 1 and Case 2 expand from the opening to the surface, making a great impact on the surrounding soil. Although the flow zones in Cases 35 are small, the soil vertical stress at the top of the tunnel will increase, which may aggravate structural safety problems of the tunnel.

\section{ACKNOWLEDGEMENT}

This study is financially supported by National Natural Science Foundation of China (Grants No. 41772295, 52090082, 51978517), Innovation Program of Shanghai Municipal Education Commission (Grant No. 2019-01-07-00-07-456 E00051) and key innovation team program of innovation talents promotion plan by MOST of China (No. 2016RA4059). Hereby, we gratefully acknowledge the financial support provided by the programs.

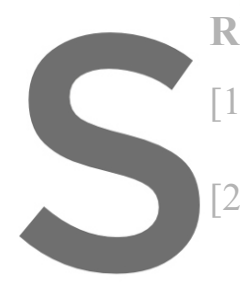

REFERENCES

1] Asakura, T. and Kojima, Space Technology (2003)

2] Huang, H. W., Chen inspection of water Sensors (2020) 20(22):6669.
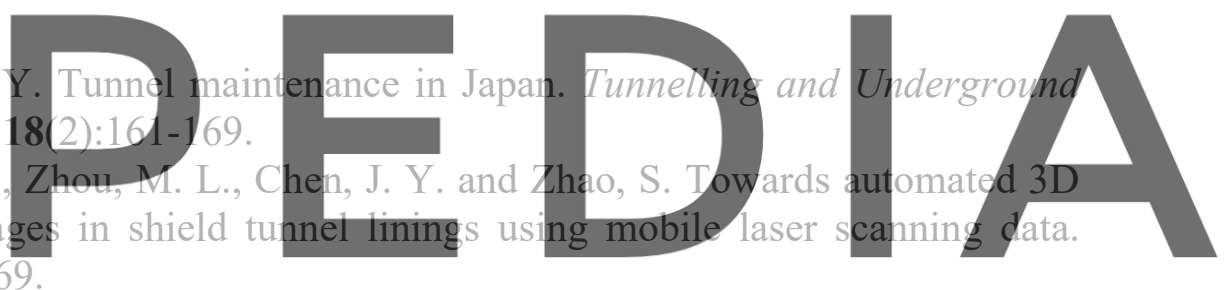

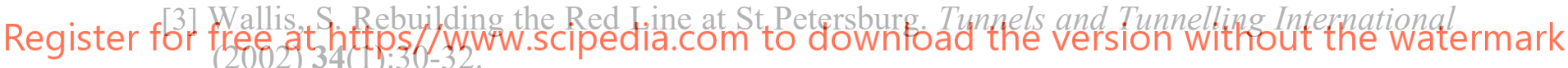

[4] Shin, J. H., Lee, I. K., Lee, Y. H. and Shin, H. S. Lessons from serial tunnel collapses during construction of the Seoul subway Line 5. Tunnelling and Underground Space Technology (2006) 21:296-297.

[5] Xu, Y. S., Shen, S. L. and Du, Y. J. Geological and hydrogeological environment in shanghai with geohazards to construction and maintenance of infrastructures. Engineering Geology (2009) 109:241-254.

[6] Cheng, W. C., Li, G., Liu, N., Xu, J. and Horpibulsuk, S. Recent massive incidents for subway construction in soft alluvial deposits of Taiwan: A review. Tunnelling and Underground Space Technology (2020) 96:103178.

[7] Zhang, D. M., Xie, X. C., Zhou, M. L., Huang, Z. K. and Zhang, D. M. An incident of water and soil gushing in a metro tunnel due to high water pressure in sandy silt. Engineering Failure Analysis (2021) 121:105196.

[8] Arjnoi, P., Jeong, J. H., Kim, C. Y. and Park, K. H. Effect of drainage conditions on porewater pressure distributions and lining stresses in drained tunnels. Tunnelling \& Underground Space Technology (2009) 24(4):376-389. 
[9] T. L. Midgley, G. A. Fox and G. V. Wilson. Seepage-induced streambank erosion and instability: In situ constant-head experiments. Journal of Hydrologic Engineering (2013) 18(10):1200-1210.

[10] Wongsaroj, J., Soga, K. and Mair, R. J. Modelling of long-term ground response to tunnelling under St James's Park, London. Géotechnique (2007) 57(1):75-90.

[11] Zhang, D. M., Gao, C. P. and Yin, Z. Y. CFD-DEM modeling of seepage erosion around shield tunnels. Tunnelling and Underground Space Technology (2019) 83:60-72.

[12] Mair, R. J. Tunnelling and geotechnics: new horizons. Géotechnique (2008) 58(9):695736.

[13] Shin, J., Kim, S. and Shin, Y. Long-term mechanical and hydraulic interaction and leakage evaluation of segmented tunnels. Soils and Foundations (2012) 52(1):38-48.

[14] Jassim, I., Stolle, D. and Vermeer, P. Two-phase dynamic analysis by material point method. International Journal for Numerical and Analytical Methods in Geomechanics numerical and Analytical Methods in Geomechanics (2013) 37:2502-2522.

[15] Bandara, S. and Soga, K. Coupling of soil deformation and pore fluid flow using material point method. Computers \& Geotechnics (2015) 63:199-214.

[16] Ceccato, F., Beuth, L., Vermeer, P. A. and Simonini, P. Two-phase material point method applied to the study of cone penetration. Computers and Geotechnics (2016) 80:440-452.

[17] Fern, E. J. Modelling tunnel-induced deformations with the material point method. Computers and Geotechnics (2019) 111:202-208.

[18] Ceccato, F., Leonardi, A., Girardi, V., Simonini, P. and Pirulli, M. Numerical and experimental investigation of saturated granular column collapse in air. Soils and Foundations (2020) 60:683-696.

[19] Anura3D. Anura3d mpm software v. 2020. www.anura3d.eu2020.

[20] Bardenhagen, S. G., Guilkey, J. E., Roessig, K. M., Brackbill, J. U., Witzel, W. M. and Foster., J. C. An improved contact algorithm for the material point method and application to stress propagation in granular material. Computer Modeling in Engineering and Sciences (2001) 2(4):509-522.

[21] Watson, G. R. and Rotter, J. M. A finite element kinematic analysis of planar granular solids flow. Chemical Engineering Science (1996) 51:3967-3978. 